\title{
The effect of body protein supply on resistance to cadmium
}

\section{GONTZEA* AND FELICIA POPESCU}

\author{
From the Nutritional Research Centre, Institute of Medicine and Pharmacy, Bucharest, Romania
}

ABSTRACT Six groups of 15 rats were fed on three diets, each differing in the quantity and quality of protein (17.87 as opposed to $8.85 \mathrm{~g} \%$, with or without the addition of $0.5 \mathrm{~g}$ methionine), one group of each pair of animals being injected subcutaneously with $0.3 \mathrm{mg} \mathrm{Cd} / \mathrm{kg}$ body weight/day, for 13 weeks. The low protein diet increased the effects of cadmium, rendering them significantly more harmful than in animals which were given the normal protein diet. The incorporation of $0.5 \mathrm{~g} \%$ DL-methionine in the low protein diet, without increasing the total nitrogen content, diminished the most marked effects induced by the same amounts of cadmium, so that their mean values were not significantly different from those found in the normal protein group treated with the same dose of the metal. The results show that a quantitatively and qualitatively adequate protein supply increases the resistance of the organism to cadmium, diminishing significantly the severity of symptoms induced by the metal.

The use of cadmium, both as the metal (for cadmium plating, in alloys containing several metals, and in cadmium-nickel accumulators) and as its salts (in dyes, stabilisers and fungicides) is becoming progressively more intensive and extensive. Its production has increased by $10 \%$ per year from 1968 , when the world production was 14000 tonnes (Rühimäki, 1972). All factories manufacturing or using this metal are potential sources not only of occupational exposure, but also of environmental pollution (Brouwers and Lauwerys, 1973). Apart from some ores, including blende ( $\mathrm{ZnS})$, the cadmium content of which may reach $4-5 \%$, the cadmium content of the earth's crust is estimated to be $0.5-1.00 \mathrm{ppm}$, but within a distance of $1.0 \mathrm{~km}$ froma zinc plant, where cadmium is also produced, its concentration in the soil to a depth of $15 \mathrm{~cm}$ has been found to be $1750 \mathrm{ppm}$ (Kloke, 1971; Buchauer, 1973; Lagerwerff et al., 1973).

In regions without industrial installations emitting cadmium, the amount does not exceed 0.001 $\mu \mathrm{g} / \mathrm{m}^{3}$ in the air and $1 \mathrm{mg} /$ litre in town water, whereas in areas where such industries exist, the cadmium concentration in air and water may be 10-20 times higher (Kopp and Kroner, 1970;

*Deceased.

Received for publication 9 February 1976 Accepted for publication 10 August 1977
Friberg et al., 1973; Page and Bingham, 1973). Raw foodstuffs may be contaminated not only through the soil, air and water, but also through the use of fertilisers (phosphates and superphosphates) or of cadmium-containing fungicides; nevertheless, their metal content is usually below $0.2 \mathrm{ppm}$, being higher in vegetable than in animal products (below 0.1 ppm) (Essing et al., 1969; Ishizaki et al., 1970; Friberg et al., 1973; Kloke, 1973; John, 1973; Thomas et al., 1973; UK Ministry of Agriculture, Fisheries and Food, 1973).

The amount absorbed daily by the human body through the digestive and respiratory routes varies between 40 and $60 \mu \mathrm{g}$ for the non-polluted regions whereas in the polluted zones it may be ten times higher (Kropf et al., 1968; Morgan, 1969; Răutu and Sporn, 1970; Friberg et al., 1973). The amount in the body increases with age and can attain $40-60 \mathrm{mg}$ in people aged 50-60 years living in contaminated areas; the highest concentration is attained in the liver and kidneys, which contain about one-third of the total body burden. In man the biological half-time of this metal, which is approximately 16 years, accounts for the accumulation and increase of the amount in the body with advancing age (Perry et al., 1961; Gul'ko, 1969; Curry and Knott, 1970; Sayato et al., 1971; Tsuchiya and Sugita, 1971; Shaikh and Lucis, 1972; Suzuki et al., 1972; Tsuchiya et al., 1972; Webb, 1972; Friberg et al., 1973). 
ADVERSE EFFECTS

Although cases of acute poisoning 0.5-3 $\mathrm{h}$ after the ingestion of doses as low as $15-20 \mathrm{mg}$ have been described, the effects of cadmium are mostly chronic and become apparent through their action on several enzymes involved in metabolic processes. On the one hand, cadmium has a marked affinity for the thiol group (Fuwa, 1971; Nordberg, 1972); on the other hand, cadmium increases the organism's needs for zinc, iron and copper (Gunn et al., 1961, 1962; Hill et al., 1963; Supplee, 1963; Hennig and Anke, 1964; Banis et al., 1969; Anke et al., 1971; Chueca et al., 1971; Pond and Walker, 1972). By its affinity for thiol and interactions with certain trace elements playing the part of coenzymes cadmium directly or indirectly alters the activity of carbonic anhydrase, acid and alkaline phosphatase, lactic and succinic dehydrogenase, $\delta$-aminolevulinic acid dehydrase, and adenosine phosphatase. Increasing the supply of the competing trace elements $(\mathrm{Zn}, \mathrm{Fe}, \mathrm{Cu})$, considerably reduces the adverse effects of cadmium, and some of its effects are eliminated (Cross et al., 1970; Hodgen et al., 1970; Adunts et al., 1972; Anca, 1973; Wada et al., 1973; Sansi and Pond, 1974).

By depressing the activity of several enzymes and by interfering with the action of some trace elements, cadmium brings about both generalised disorders (hyperglycaemia, dyslipidaemia, hypoproteinaemia, and retarded growth, for example) and also morphological changes in several tissues or organs, leading to nephropathy, hepatopathy, anaemia, cardiovascular disease, osteopathy and gonadal lesions. It is therefore considered to be a factor that may increase morbidity and mortality, and reduce longevity (Kazantzis et al., 1963; Piscator, 1963; Axelsson and Piscator, 1966a, b; Carroll, 1966; Schroeder, 1967; Tsuchiya, 1967; Lilis et al., 1968; Fukuyama and Kubota, 1970; Gunn, 1970; Pujol et al., 1970; Anke et al., 1971; Flick et al., 1971; Mertz et al., 1972; Nordberg and Piscator, 1972; Perry, 1972; Itokawa et al., 1973;).

Pollution of the environment can be prevented only by organisation and technical measures, but industrialisation inevitably entails some dispersion of chemical agents into the environment. Because the result of the action of a chemical on the body depends not only on its toxicity but also on the host's reaction, which is influenced to a great extent by his state of nutrition, we have studied the role of diet in the body's resistance to such toxicants (Gontzea et al., 1964; Gontzea et al., 1967; Gontzea and Sutzescu, 1967).

As chronic cadmium toxicity causes impairment of the activity of several enzymes and alters the available nitrogenous material, we have studied the quantity and quality of protein intake (Smith et al., 1961; Piscator, 1962, 1966; Gunn et al., 1966; Tsuchiya, 1967; Fuwa, 1971; Goyer et al., 1972; Nordberg, 1972; Friberg et al., 1973).

\section{Materials and methods}

Ninety white male young rats of the Wistar strain, and of similar age and weight (180-190 g) were fed with a semi-synthetic mixture containing casein, starch and sunflower oil, to which were added vitamins and mineral salts in optimal ratios. The two variables were the amount $(17.87 \mathrm{~g} \%$ in the normal protein diet, and $8.85 \mathrm{~g} \%$ in the low protein diet) and the quality of the nitrogenous material. As the amino acid with the greatest affinity for cadmium is cysteine and the thioamino acids represent the limiting factor of casein, the variation of quality was achieved by isonitrogenous substitution in the low protein diet of $0.5 \mathrm{~g} \% \mathrm{DL}$-methionine. Food and water were given ad libitum. In order that, at the start of cadmium administration, the animals' state of nutrition should be comparable, they were fed for 10 days on a normal protein diet. They were subsequently randomly allocated to three groups corresponding to the three diets (normal protein, low protein with methionine, or low protein without the addition of methionine.)

The animals in each dietary group were further divided into two subgroups, one of which was treated with cadmium, the other subgroup acting as a control. The toxicant was added as cadmium chloride dissolved in normal saline in a concentration of $30 \mu \mathrm{g}$ cadmium $/ 0 \cdot 1 \mathrm{ml}$. To maintain the isotonicity of the solution the concentration of sodium chloride in the normal salt solution was equiosmotically reduced. In order to know exactly how much metal entered the metabolism, the solution was administered subcutaneously, to give $0.3 \mathrm{mg}$ $\mathrm{Cd} / \mathrm{kg}$ body weight (65-70 times less than the LD $\mathrm{D}_{50}$ ), six times a week for 13 weeks. So that the effects of neuroendocrine stress caused by the injection per se could be ruled out, the control animals were injected subcutaneously with the same amount and with the same frequency as were the test animals, using the vehicle only $(0.8 \mathrm{~g} \% \mathrm{NaCl})$.

During the experiment the body weights were recorded weekly, and haematology and blood sugar were monitored monthly. At the end of the period, after all these examinations had been repeated, the animals were anaesthetised and killed by withdrawal of blood from the heart until it stopped beating, and by excision of the liver. The concentrations of cholesterol and protein in serum were measured, as was the protein content of liver homogenate and the activity of the enzymes xanthine oxidase, succinic dehydrogenase and aldolase. 
Table 1 The effects of protein supply and cadmium on body weight and blood chemistry

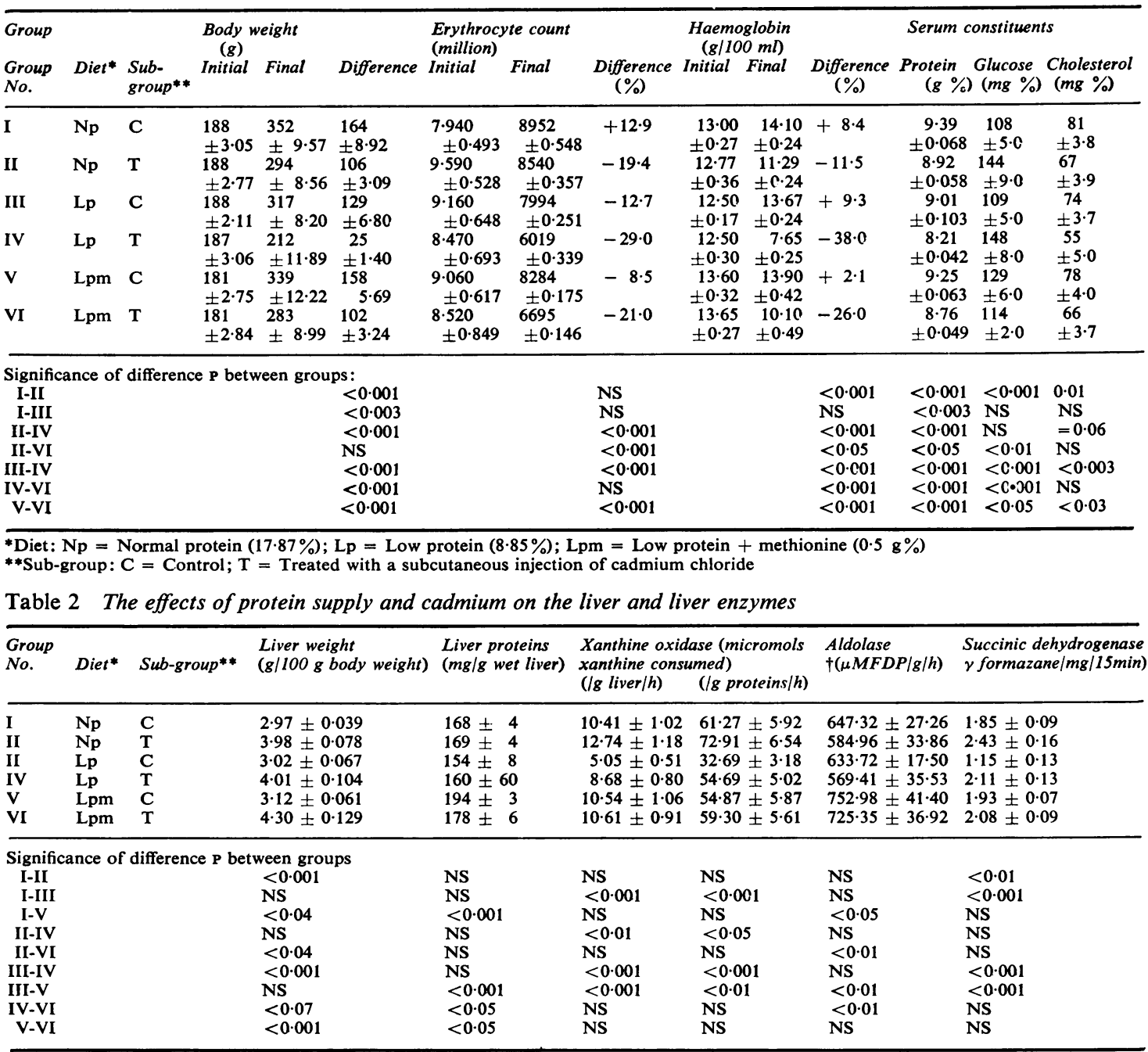

* Diet: As in Table

* Sub-group: As in Table 1

$+\mu \mathrm{MFDP}=\mu \mathrm{mol}$ fructose $-1,6$-diphosphate

\section{Results and discussion}

The average values and standard errors of each group are shown in Tables 1 and 2. The results were interpreted by comparison both between groups and between pairs, and only those differences which were statistically significant at $P<0.05$ were taken into account.

\section{BODY WEIGHT}

Irrespective of the diet of the animals injected with cadmium, their weight increase was significantly
$(P<0.001)$ less than that of the control groups, demonstrating the effects of the doses administered (Table 1 and Figure 1). In the pairs with a normal protein diet the difference between the dosed group and the control group was $30 \%$, whereas in the low protein pair the weight increase was five times smaller in the cadmium-treated animals $(+13.4$ against $68.6 \mathrm{~g}$ ). The improvement in quality of the nitrogenous material in the low protein diet, following the addition of methionine, allowed the animals to achieve the same weight increase $(+56 \%)$ as the animals treated with the same dose of cad- 


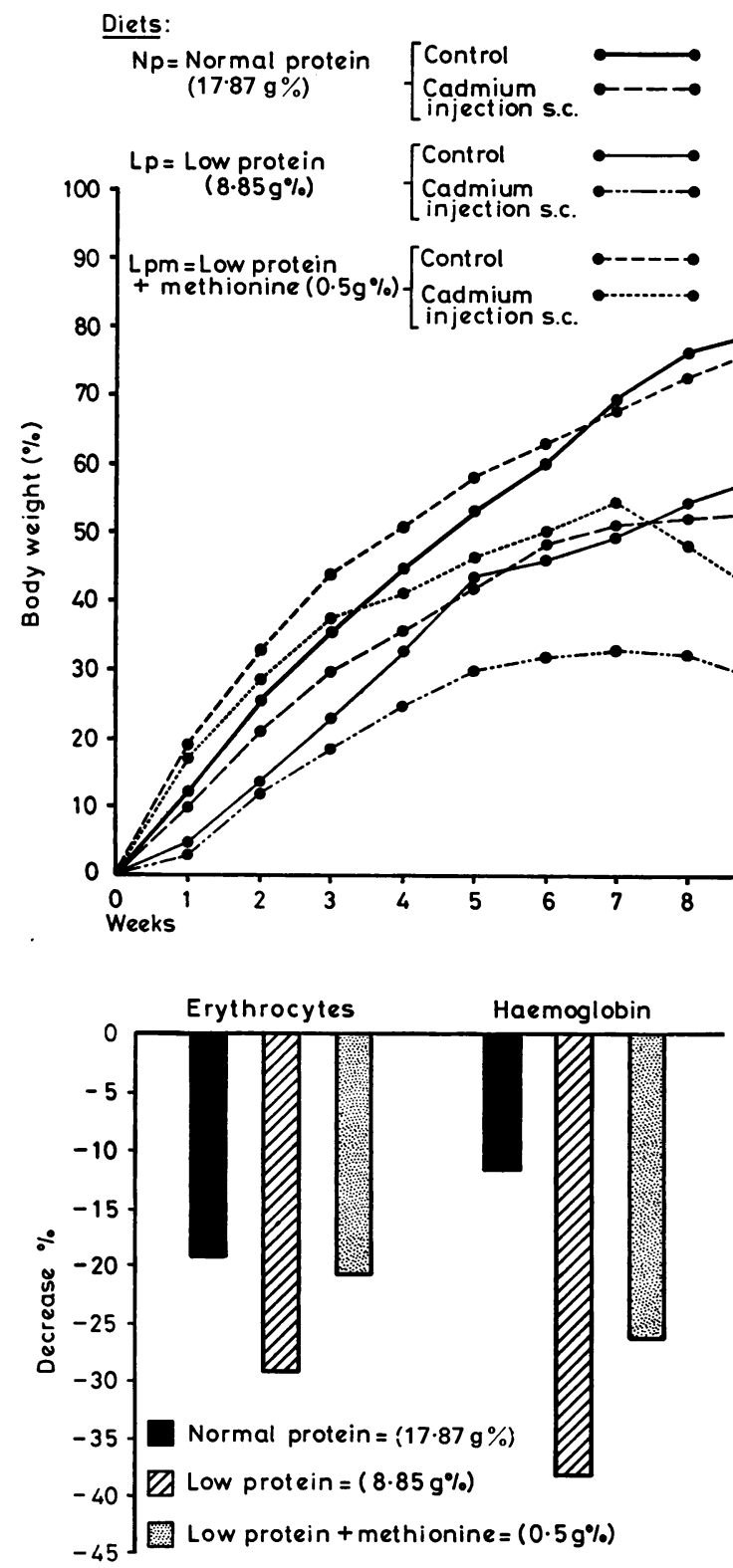

Fig. 2 The role of protein supply on the effect of cadmium $(0.3 \mathrm{mg} / \mathrm{kg}$ body weight $)$ on erythrocytes and haemoglobin levels.

mium but maintained on the normal protein diet. These results demonstrate that the quality, in other words, the ratio of essential amino acids, particularly the thioamino acids, and to a lesser degree, the quantity, is decisive for the protective role of the proteins in the diet.
Fig. 1 Influence of diet on increase in body weight (as percentages of initial values) after subcutaneous injection of $0.3 \mathrm{mg} \mathrm{Cd} / \mathrm{kg}$ body weight. 
Leaving aside the pair fed on the low protein diet fortified with methionine, in which cadmium lowered the mean value of glucose $(P<0.05)$, in the other two pairs the administration of the same amount of cadmium caused a significant increase $(\mathrm{P}<0.001)$ in the blood glucose concentration (by 33-35\%). The hyperglycaemic action of cadmium was not influenced by the protein supply. Irrespective of the diet, the mean level of cholesterol in animals of the groups treated with cadmium was lower than that in the control groups, but the significance of the differences is relatively reduced $(P=0.06-P<0.01)$, being only slightly influenced by the diet, with the highest value recorded for the low protein pair.

\section{THE EFFECTS OF CADMIUM ON THE LIVER}

\section{AND LIVER ENZYMES}

Regardless of the quantity and quality of protein in the diet, cadmium administration increased $(\mathrm{P}<0.001)$ the weight of liver $/ 100 \mathrm{~g}$ body weight (Table 2). In the control animals, adding $0.5 \mathrm{~g}$ methionine to the low protein diet without changing its total nitrogen content, significantly increased $(\mathrm{P}<0.001)$ the protein concentration in the liver, both by comparison with the normal protein control group and with the group fed on the low protein diet. As expected, in the animals of the control group the low protein diet significantly lowered $(P<0.001)$ the xanthine oxidase and succinic dehydrogenase activity. The addition of $0.5 \mathrm{~g} \%$ DL-methionine counteracted this effect, so that the differences with regard to the normal protein group became non-significant, and aldolase activity was increased $(P<0.05)$.

The fact that the quantity and quality of the protein supply significantly diminishes the effect of cadmium on weight increase, haematopoiesis and protein content, shows that poisoning by this metal is particularly detrimental either to the amino acids available in the metabolic pool, or to their anabolic use. These effects may be caused by loss of nitrogenous material (proteinuria, hyperaminoaciduria), and particularly by inactivation of the thiol groups and by binding of a part of the amino acids in the form of metallothionine, which plays an important part in the elimination of cadmium from the body.

\section{References}

Adunts, G. T., Parsadanyan, G. K., and Ter-Tatevosyan, L. P. (1972). Effect of cadmium ions on the alkaline phosphatase activity of white rats during ontogenesis. Biologičeskij Žurnal Armenii, 25, 10-15.

Anca, Z. (1973). Acțiunea ionilor de cadmium asupra unor sisteme de dehidrogenare pe rinichi izolat și perfuzat la şobolani. (Action of cadmium ions on certain dehydro- genation systems in isolated and perfused rat kidneys). Studii şi Cercetări de Biochimie, 16, 5-8.

Anke, M., Hennig, A., Groppel, B., and Leudke, H. (1971). Effect of cadmium on growth, reproductive function, and the metabolism of iron, zinc and copper. Archiv für experimentelle Veterinärmedizin (Leipzig). 25, 799-803.

Axelsson, B., and Piscator, M. (1966a). Renal damage after prolonged exposure to cadmium. Archives of Environmental Health, 12, 360-373.

Axelsson, B., and Piscator, M. (1966b). Serum proteins in cadmium-poisoned rabbits with special reference to hemolytic anemia. Archives of Environmental Health, 12, 374-381.

Banis, R. J., Pond, W. G., Walker, E. F. (Jr.), and O'Connor, J. R. (1969). Dietary cadmium, iron and zinc interactions in the growing rat. Proceedings of the Society for Experimental Biology and Medicine, 130, 802-806.

Brouwers, J., and Lauwerys, R. (1973). Les effets toxiques du cadmium. Archives des Maladies Professionnelles de Médecine du Travail et de Sécurité Sociale, 34, 127-136.

Buchauer, M. J. (1973). Contamination of soil and vegetation near a zinc smelter by zinc, cadmium, copper and lead. Environmental Science and Technology, 7, 131-135. Carroll, R. E. (1966). Relationship of cadmium in the air to cardiovascular disease death rates. Journal of the American Medical Association, 198, 267-270.

Chueca, A., Garcia del Amo, C., and Santos-Ruiz, A. (1971). Interference of $\mathrm{Cd}^{++}$on the turnover of zinc orally administered. Revista Espańola di Fisiología, 27, 143-148.

Cross, C. E., Ibrahim, A. B., Ahmed, M., and Mustafa, M. G. (1970). Effect of cadmium ion on respiration and ATP-ase activity of the pulmonary alveolar macrophage. Environmental Research, 3, 512-520.

Curry, A. S., and Knott, A. R. (1970). 'Normal' levels of cadmium in human liver and kidney in England. Clinica Chimica Acta, 30, 115-118.

Essing, H. G., Schaller, K. H., Szadkowski, D., and Lehnert, G. (1969). Usuelle Cadmiumbelastung durch Nahrungsmittel und Getränke. Archiv für Hygiene und Bakteriologie, 153, 490-494.

Flick, D. F., Kraybill, H. F., and Dimitroff, J. M. (1971). Toxic effects of cadmium. Environmental Research, 4, 71-85.

Friberg, L., Piscator, M., Nordberg, G., and Kjellström, T. (1973). Cadmium in the environment, II. US National Technical Information Service, Report No.221 198/5, p.173.

Fukuyama, Y., and Kubota, K, (1970). Osteopathy and nephropathy in the inhabitants of a cadmium-polluted district. Igaku To Seibutsugaku, 81, 37-42.

Fuwa, K. (1971). Cadmium in the human body as metallothionine. Kagaku (Tokyo), 41, 569-574.

Gontzea, I., and Sutzescu, P. (1967). Alimentația și profilaxia saturnismului. (Nutrition and prevention of saturnism), pp. 183-254. Studii și Cercetări pentru Sănătate Publică: Institutul de Igienă București.

Gontzea, I., Sutzescu, P., Cocora, D., and Lungu, D. (1964). L'importance de l'apport de protéines sur la résistance de l'organisme à l'intoxication par le plomb. Archives des Sciences Physiologiques, 18, 211-224.

Gontzea, I., Sutzescu, P., Cocora, D., and Rujinski, A. (1967). Influența metioninei asupra intoxicației cu plumb la șobolan. (Influence of methionine on lead poisoning in rats). Igiena, 16, 459-464.

Goyer, R. A., Tsuchiya, K., Leonard, D. L., and Kahyo, H. (1972). Aminoaciduria in Japanese workers in the lead and cadmium industries. American Journal of Clinical Pathology, 57, 635-642.

Gul'ko, V. V. (1969). Age-dependent relation of zinc and cadmium in the human liver and kidneys. In Obmen Funkts Stareyushchego Organizma, pp. 11-15. Edited by L. Mikhailova and V. D. Izd. Tekhika: Minsk, USSR. 
Gunn, S. A. (1970). The effects of cadmium on the male reproductive system. Morphological Aspects of Andrology, 1, 58-61.

Gunn, S. A., Gould, T. C., and Anderson, W. A. (1961). Zinc protection against cadmium injury to rat testis. Archives of Pathology (Chicago), 71, 274-281.

Gunn, S. A., Gould, T. C., and Anderson, W. A. (1962). Interference with fecal excretion of $\mathrm{Zn}^{65}$ by cadmium. Proceedings of the Society for Experimental Biology and Medicine, 111, 559-562.

Gunn, S. A., Gould, T. C., and Anderson, W. A. (1966). Protective effect of thiol compounds against cadmiuminduced vascular damage to testis. Proceedings of the Society for Experimental Biology and Medicine, 122, 1036-1039.

Hennig, A., and Anke, M. (1964). Kadmium-Antimetabolit des Eisens und Zinks. Archiv für Tierernährung, 14, 55-57.

Hill, C. H., Matrone, G., Payne, W. L., and Barber, C. W. (1963). In vivo interaction of cadmium with copper, zinc and iron. Journal of Nutrition, 80, 227-235.

Hodgen, G. D., Gomes Wayne, R., and Vandemark, N. L. (1970). In vitro and in vivo effects of cadmium chloride on isoenzymes of carbonic anhydrase in rat testes and erythrocytes. Biology of Reproduction (New York), 2 , 197-201.

Ishizaki, A., Fukushima, M., and Sakamoto, M. (1970). Distribution of cadmium in biological materials. 2 . Cadmium and zinc contents of foods. Nippon Eiseigaku Zasshi, 25, 207-222.

Itokawa, Y., Abe, T., and Tanaka, S. (1973). Bone changes in experimental chronic cadmium poisoning. Radiological and biological approaches. Archives of Environmental Health, 26, 241-244.

John, M. K. (1973). Cadmium uptake by eight food crops as influenced by various soil levels of cadmium. Environmental Pollution, 4, 7-15.

Kazantzis, G., Flynn, F. V., and Spowage, J. S. (1963). Renal tubular malfunction and pulmonary emphysema in cadmium pigment workers. Quarterly Journal of Medicine, 32, 165-191.

Kloke, A. (1971). Cadmium in soils and plants. Environmental protection. Nachrichtenblatt Deutsches Pfanzenschutzdienstes (Brunswick), 23, 164-167.

Kloke, A. (1973). Heavy metals in foods and forage plants. Deutsche Lebensmittel-Rundschau, 69, 45-49.

Kopp, J. F., and Kroner, R. C. (1970). Trace metals in waters of the United States. US Department of the Interior: Cincinnati, Ohio.

Kropf, R., Geldmacher, M., and Mallincrodt, V. (1968). Der Cadmiumgehalt von Nahrungsmitteln und die tägliche Cadmiumaufnahme. Archiv für Hygiene und Bakteriologie, 152, 218-224.

Lagerwerff, J. V., Brower, D. L., and Biersdorf, G. T. (1973). Accumulation of cadmium, copper, lead and zinc in soil and vegetation in the proximity of a smelter. In Trace Substances in Environmental Health. VI Symposium p. 71-78. Edited by D. D. Hemphill. University of Missouri: Columbia.

Lilis, R., Gavrilescu, N., and Nestorescu, B. (1968). Nephropathy in chronic lead poisoning. British Journal of Industrial Medicine, 25, 196-202.

Mertz, D. P., Koschnick, R., and Wilk, G. (1972). Renal excretion of cadmium in normotensive and hypertensive humans. Zeitschrift für Klinische Chemie und Klinische Biochemie (Berlin), 10, 21-24.

Morgan, J. M. (1969). Tissue cadmium concentration in man. Archives of Internal Medicine, 123, 405-408.

Nordberg, G. F. (1972). Cadmium metabolism and toxicity. Environmental Physiology andBiochemistry (Copenhagen), 2, 7-36.
Nordberg, G. F., and Piscator, M. (1972). Influence of long-term cadmium exposure on urinary excretion of protein and cadmium in mice. Environmental Physiology and Biochemistry (Kobenhavn), 2, 37-49.

Page, A. L., and Bingham, F. T. (1973). Cadmium residues in the environment. Residue Reviews, 48, 1-44.

Perry, H. M. (Jr.). (1972). Hypertension and the geochemical environment. Annals of the New York Academy of Sciences, 199, 202-216.

Perry, H. M., Tripton, I. H., Schroeder, H. A., Steiner, R. L., and Cook, M. J. (1961). Variation in concentration of cadmium in human kidneys as a function of age and geographic origin. Journal of Chronic Diseases, 14, 259-272.

Piscator, M. (1962). Proteinuria in chronic cadmium poisoning. Archives of Environmental Health, 4, 607-621.

Piscator, M. (1963). Haemolytic anaemia in cadmium poisoned rabbits. In Proceedings of the Fourteenth International Congress in Occupational Health (Madrid), p. 925-928.

Piscator, M. (1966). Proteinuria in chronic cadmium poisoning. Archives of Environmental Health, 12, 335-344.

Pond, W. G., and Walker, E. F. (Jr.) (1972). Cadmiuminduced anemia in growing rats: prevention by oral or parenteral iron. Nutrition Reports International, 5, 365-370.

Pujol, M., Arlet, J., Bollinelli, R., and Carles, P. (1970). Tubulopathie des intoxications chroniques par le cadmium. Archives des Maladies Professionnelles de Médecine du Travail et de Sécurité Sociale, 31, 637-646.

Răutu, R., and Sporn, A. (1970). Beiträge zur Bestimmung der Cadmiumzufuhr durch Lebensmittel. Nahrung, 14, 25-31.

Rühimäki, V. (1972). Cadmium. Occurrence and effects. Work-Environment-Health, 9, 91-101.

Sansi, K. A. O., and Pond, W. G. (1974). Pathology of dietary cadmium toxicity in growing rats and the protective effect of injected iron. Nutrition Reports International, 9, 407-414.

Sayato, Y., Hasegawa, A., and Ando, M. (1971). Hygienic chemical studies on poisonous metals. I. Body retention, excretion and distribution pattern of cadmium. Eisei Kagaku, 17, 398-403.

Schroeder, H. A. (1967). Cadmium, chromium and cardiovascular disease. Circulation, 35, 570-582.

Shaikh, Z. A., and Lucis, O. J. (1972). Cadmium and zinc binding in mammalian liver and kidneys. Archives of Environmental Health, 24, 419-425.

Smith, J. C., Wells, A. R., and Kench, J. E. (1961). Observations on the urinary protein of men exposed to cadmium dust and fume. British Journal of Industrial Medicine, 18, 70-77.

Supplee, W. C. (1963). Antagonistic relationship between dietary cadmium and zinc. Science, 139, 119-120.

Suzuki, S., Taguchi, T., and Yakohashi, G. (1972). Retention rate and organ distribution of cadmium following a single oral dose in a monkey. Sangyo Igaku, 14, 130-131.

Thomas, B., Roughan, J. A., and Watters, E. D. (1973). Lead and cadmium content of some canned fruit and vegetables. Journal of the Science of Food and Agriculture, 24, 447-449.

Tsuchiya, K. (1967). Proteinuria of workers exposed to cadmium fume. The relationship to concentration in the working environment. Archives of Environmental Health. 14, 875-880.

Tsuchiya, K., Saki, Y., and Sugita, M. (1972). Organ and tissue cadmium concentrations of cadavers from accidental deaths. In Proceedings of the XVII International Congress in Occupational Health.

Tsuchiya, K., and Sugita, M. (1971). A mathematical model for deriving the biological half-life of a chemical. 
Särtryck ur Nordisk Hygienisk Tidskrift, Tokyo, 53, 105-110.

UK Ministry of Agriculture, Fisheries and Food. (1973). Survey of cadmium in food. Fourth report of the Working Party on the Monitoring of Foodstuffs for Heavy Metals. SBN 11-240533-9. HMSO: London.
Wada, O., Jano, Y., Ono, T., and Toyakawa, K. (1973). Interaction of cadmium and organic mercury compounds against the activity of delta-aminolevulinic acid dehydrase in vitro. Industrial Health, 10, 59-61.

Webb, M. (1972). Binding of cadmium ions by rat liver and kidney. Biochemical Pharmacology, 21, 2751-2765. 